\title{
Positive serology for viral hepatitis and donor self-exclusion in Southern Brazil
}

\author{
Julia De Luca Maccarini ${ }^{[1]}$, Carlos Alberto Kuntz Nazario ${ }^{[1]}$, Jovino dos Santos Ferreira ${ }^{[2]}$, \\ William Queiroz Guimarães Wiegandt Ceglio ${ }^{[2]}$, Rômulo Cavalcante Serpa ${ }^{[2]}$, \\ Vera Lúcia Paes Cavalcanti Ferreira ${ }^{[2]}$, Leonardo de Lucca Schiavon ${ }^{[1]}$ \\ and Janaína Luz Narciso-Schiavon ${ }^{[1]}$
}

[1]. Núcleo de Estudos em Gastroenterologia e Hepatologia, Universidade Federal de Santa Catarina, Florianópolis, SC. [2]. Serviço de Hemoterapia, Hospital Universitário Polydoro Ernani de São Thiago, Florianópolis, SC.

\begin{abstract}
Introduction: Despite the great advances in serological testing for transfusion-transmitted infections, the selection of blood donors by blood bank operators remains the only way to avoid transmission within the testing window period. Part of this selection is the self-exclusion form, on which the donors can exclude their blood from donation without any explanation. This study assessed the clinical and epidemiological characteristics related to positivity for viral hepatitis and to the use of the confidential self-exclusion (CSE) form. Methods: This transversal study analyzed the data collected from blood donors' files in a hospital in Southern Brazil. Univariate and multivariate analyses identified the clinical and epidemiological variables related to positive serologies of viral hepatitis and to whether the donor was self-excluded. Results: Of the 3,180 donors included in this study, $0.1 \%$ tested positive for $\mathrm{HBsAg}, 2.1 \%$ for anti-HBc, and $0.9 \%$ for anti-HCV. When the 93 donors with positive serologies for viral hepatitis were compared with those who were negative, a greater proportion of the positive serology group was found to have had a history of blood transfusions $(\mathrm{OR}=4.908 ; 95 \% \mathrm{CI}=1.628-14.799 ; \mathrm{p}<0.01)$, had repeatedly donated $(\mathrm{OR}=2.147$; $95 \% \mathrm{CI}=1.236-3.729 ; \mathrm{p}<0.01)$, and used the $\mathrm{CSE}$ form for self-exclusion $(\mathrm{OR}=7.139 ; 95 \% \mathrm{CI}=2.045-24.923 ; \mathrm{p}<0.01)$. No variables were independently associated with self-exclusion. Conclusions: A history of blood transfusion, repeated donations, and self-exclusion are factors that should be considered during viral hepatitis screenings in blood banks.
\end{abstract}

Keywords: Hepatitis B. Hepatitis C. Blood donors.

\section{INTRODUCTION}

Worldwide, there are approximately 400 million hepatitis $\mathrm{B}$ virus (HBV) carriers and 170 million individuals chronically infected with the hepatitis $\mathrm{C}$ virus $(\mathrm{HCV})^{1,2}$. The prevalences of hepatitis B in south-central Brazil and the northern region of Brazil are 2 and $8 \%$, respectively ${ }^{2}$. The prevalence of hepatitis $\mathrm{C}$ is $0.8 \%$ among all Brazilian blood donors $(2.1 \%$ for northern donors and $0.7 \%$ for southern donors) ${ }^{3-5}$. Although hepatitis B has a high risk of vertical, horizontal, and sexual transmission, parenteral transmission is the most common means of transmission for both hepatitis $\mathrm{B}$ and $\mathrm{C}^{1}$. The main risk factors for parenteral transmission are intravenous drug use and blood and hemocomponent transfusions ${ }^{1}$.

In the State of Santa Catarina, in Southern Brazil, the residual risk of $\mathrm{HBV}$ transmission by transfusion during the

\footnotetext{
Address to: Drª Janaína Luz Narciso-Schiavon. Dept ${ }^{\circ}$ Clínica Médica/HU Polydoro Ernani de São Thiago/UFSC. Rua Professora Maria Flora Pausewang $\mathrm{s} / \mathrm{n}^{\circ}, 3^{\circ}$ andar, Trindade, 88040-900 Florianópolis, SC, Brasil.

Phone: 5548 3721-9014

e-mail: janaina.narciso@uol.com.br

Received 3 May 2013

Accepted 17 July 2013
}

testing window period is estimated to be 1 in every 15,400 donations, which is 16 times higher than that reported in the United States $(1: 250,000)^{6,7}$. For HCV, the residual risk is one in every 127,300 donations, which is 12 times higher than the risk found in the United States ${ }^{7}$. In Australia, this risk is estimated at approximately 1 in 633,000 transfusions for hepatitis B and 1 in 6,387,000 transfusions for hepatitis $\mathrm{C}^{8}$.

Post-transfusion hepatitis (PTH) was first described in 1943. Studies evaluating the risk criteria for transmissible infectious diseases in blood donors began in the 1960s and 1970s and compared voluntary and commercial donations ${ }^{9-11}$. For a long time, a viral etiology was suspected for PTH; in 1965, the Australia antigen was discovered and was later called the hepatitis B surface antigen (HBsAg) $)^{12-15}$. After the discovery of the hepatitis A virus and its exclusion as the PTH cause, it became clear that a large portion of PTH was caused by other unknown viruses; such infections were called non-A non-B hepatitis (NANB hepatitis) ${ }^{16-18}$. In the 1970s and 1980s, extensive research was conducted to establish the etiologic agent of NANB hepatitis, leading to the discovery of the hepatitis C virus in $1989^{19,20}$. Since then, recent studies have established that $80-90 \%$ of NANB hepatitis is caused by $\mathrm{HCV}^{12,19-21}$.

Safety in blood donation is a major concern at blood transfusion centers ${ }^{22}$. Efforts to guarantee safety focus on ensuring a supply of suitable blood bags, selecting healthy donors, and preventing donations by individuals at an increased 
risk of transfusion transmissible infections ${ }^{23}$. Despite the development of assays to detect infectious diseases, transmission by transfusion still occurs for reasons such as the testing window period, the convalescent phase of an $\mathrm{HBV}$ infection, or a chronic $\mathrm{HBV}$ infection with a low $\mathrm{HBsAg}^{7,24-26}$. Additionally, new pathogens transmitted by risky behavior that are not yet tested in blood donors may appear ${ }^{26}$.

The selection of donors is still the only way to prevent the transmission of infected blood donated during the immunological testing window ${ }^{8,27,28}$. One of the steps in this selection is the confidential self-exclusion (CSE) form on which the blood donors can exclude their donated blood without providing any justification ${ }^{28,29}$. Donors who self-exclude could do so because they think that they have risk factors or because they are donating blood to obtain their serological test results ${ }^{29}$.

The first CSE system was developed in the United States in 1984, and since then, similar systems have been used in several countries $^{22}$. In Brazil, the use of CSE has been mandatory with blood donations since $2003^{30,31}$. Few studies have evaluated the effectiveness of CSE in preventing the transmission of infectious diseases by blood donation ${ }^{26,28}$, so this study aimed to evaluate the clinical and epidemiological characteristics associated with a positive serology for hepatitis $\mathrm{B}$ and $\mathrm{C}$ and with the use of the CSE form.

\section{METHODS}

\section{Subjects}

This cross-sectional study reviewed the records of blood donations at the Blood Bank of the University Hospital of the Federal University of Santa Catarina (HU/UFSC). The subjects were adults who met the selection criteria of the blood bank and who donated blood between January 2009 and December 2010. Individuals who were seropositive for human immunodeficiency virus (HIV), had insufficient records of clinical and laboratory data, and made repeated donations were excluded from the study (only the first donation was included).

\section{Methods}

Epidemiological, laboratory, and other clinical variables were obtained from histories taken during routine donations at the blood bank. Patients were evaluated for a positive viral hepatitis serology. Those individuals who showed a positive or indeterminate $\mathrm{HBsAg}$, a reactive or indeterminate antibody to hepatitis B core antigen (anti-HBc), or a reactive or indeterminate anti-HCV were considered positive.

The clinical and epidemiological variables assessed in the study were the following: age (in years), gender, ethnicity (Caucasian or not), marital status (married, in a stable relationship, single, separated, divorced, or widowed), education (in years), having a homosexual relationship, body mass index (defined as weight $/$ height $^{2}$ ), being a healthcare professional, history of previous surgery, history of receiving blood transfusions, sexual promiscuity (two or more partners in the last year), previous use of illicit drugs, tattoos, reason for donation (spontaneous: unselfish donation, made with a caring attitude; or directed: donation bound or tied to a patient), first donation or not, donation with the intention of obtaining the serology results, and CSE status (suggestion of the donor after the interview that their blood should be discarded).

\section{Statistical analysis}

The continuous variables were analyzed using Student's t-test or the Mann-Whitney test, when appropriate. The categorical variables were compared using the chi-square $\left(\chi^{2}\right)$ or Fisher's exact test. A p-value $<0.05$ indicated statistical significance. A comparative analysis of the data was performed according to the serological positivity for viral hepatitis. A logistic regression analysis was used to identify the variables that were independently associated with the presence of positive serologic tests for viral hepatitis. An analysis comparing the data with the CSE decision was also performed. All of the tests were performed by the statistical program Statistical Package for the Social Sciences, Version 17.0 (SPSS Inc., Chicago, IL, USA).

\section{Ethical considerations}

This study complied with the ethical recommendations of the Helsinki Declaration of 2000 and was approved by our institutional review board under the number 1900 .

\section{RESULTS}

\section{Patient characteristics}

During 2009 and 2010, 4,684 blood donations were collected at the Blood Bank of the HU/UFSC. Of these donations, 1,482 were excluded because they were donated by the same donor (repeated donations), 13 were excluded due to insufficient data, and 9 were excluded due to reactive HIV serology. Therefore, the study included 3,180 individual donors (Figure 1).

Of the donors with a positive serology for viral hepatitis, two had a positive or indeterminate HBsAg test (both were also reactive for anti-HBc). Sixty-three donors were reactive for anti-HBc alone, and 28 were anti-HCV reactive or indeterminate ( 2 of these 28 donors were also reactive for anti-HBc), totaling 93 individuals with a positive serology for viral hepatitis. Among the donors who presented as reactive for anti-HBc alone, 43 were also tested for anti-HBs, with 24 found to be reactive, 18 found to be negative, and 1 with an indeterminate result (Figure 2).

The demographic characteristics of the 3,180 blood donors included in the study were as follows: the mean age was $27.2 \pm 9.7$ years, $59.4 \%$ were men, $96.2 \%$ were Caucasian, $20.8 \%$ were married or were in a stable relationship, $97.2 \%$ had undergone more than 8 years of education, and $23.4 \%$ were either overweight or obese. The epidemiological characteristics of the donors were as follows: $9.9 \%$ were health professionals, $21.6 \%$ had undergone previous surgery, $0.9 \%$ had undergone blood transfusion, $0.3 \%$ had previously used illicit drugs, and $8.1 \%$ had a tattoo. With regard to the reasons for donating blood, $11.2 \%$ donors were relatives or friends of patients (direct 
Blood donations between 2009 and 2010

$n=4,684$

Excluded:

- repeated donations $(n=1,482)$

- insufficient data $(n=13)$

- $\operatorname{HIV}(n=9)$

Blood donors included

$n=3,180$

FIGURE 1 - Flow diagram of the potential candidates for inclusion in the study, reasons for exclusion, and subjects enrolled. HIV: Human immunodeficiency virus.

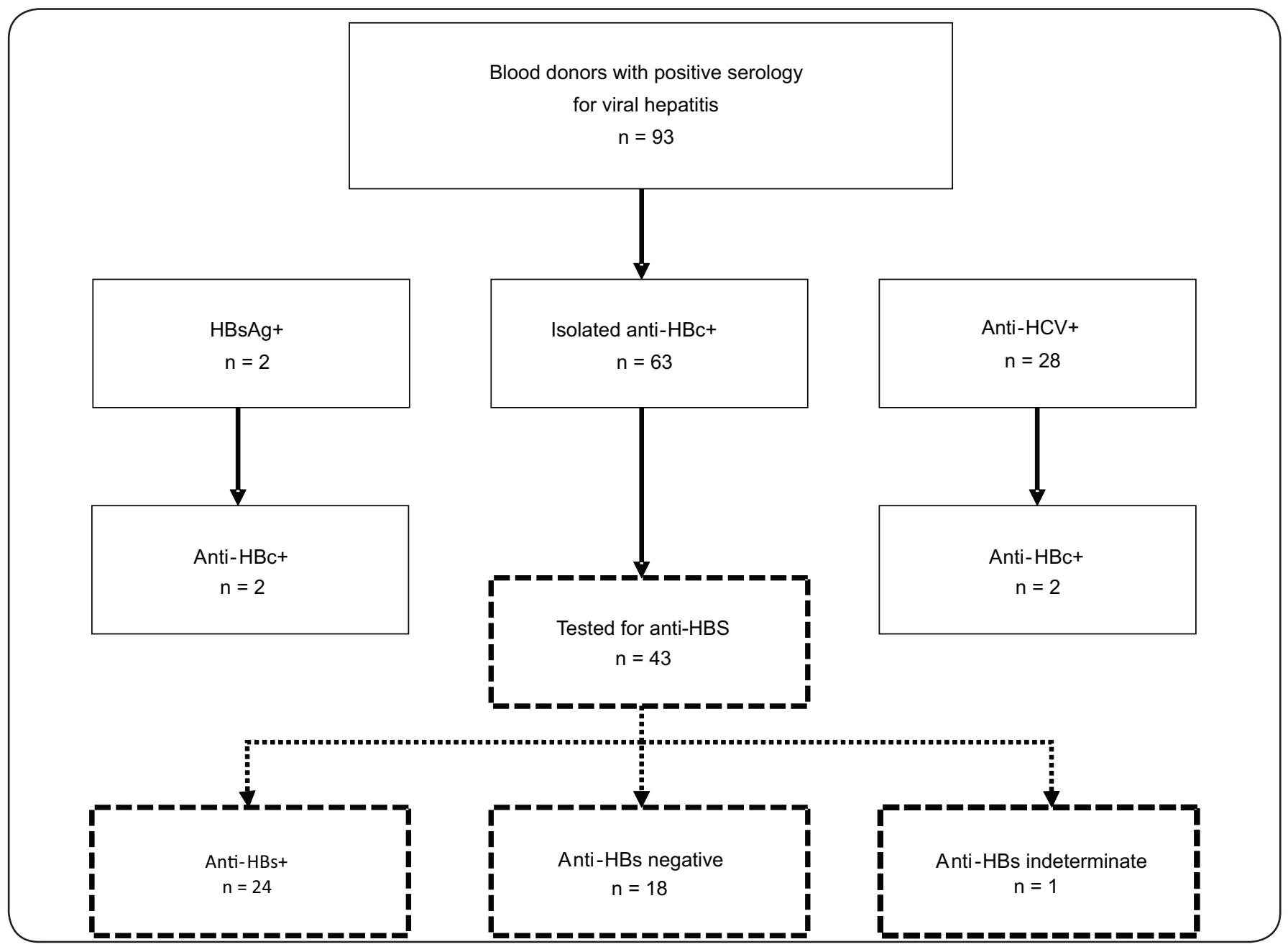

FIGURE 2 - Flow diagram of the 93 blood donors with positive serology for viral hepatitis. HBsAg: hepatitis B surface antigen; anti-HBc: antibody to hepatitis $\mathrm{B}$ core antigen; anti-HCV: antibody to hepatitis C virus; anti-HBs: antibody to hepatitis B surface antigen. 
donation), $55.3 \%$ donated for the first time, and $0.1 \%$ donated to obtain the results of the blood exams. Among all the individuals included in the study, $0.7 \%$ chose self-exclusion of their blood.

\section{Comparative analysis of individuals with positive serology}

Compared with individuals with negative serology for viral hepatitis, those with positive serology had higher rates of being in a stable relationship or marriage (33.3\% vs $20.4 \%$, $\mathrm{p}<0.01)$, having a past history of blood transfusion $(4.3 \%$ vs $0.8 \%, \mathrm{p}<0.01)$, giving a directed donation $(23.7 \%$ vs $10.8 \%, \mathrm{p}<0.01)$, giving their first donation $(62 \%$ vs $44.2 \%$, $\mathrm{p}<0.01)$, and choosing to self-exclude ( $3.3 \%$ vs $0.6 \%, \mathrm{p}=0.02)$ (Table 1). Furthermore, donors with positive serology had less frequently attended the complete compulsory education program (93.4\% vs $97.3 \%, \mathrm{p}=0.04)$.

The multivariate analysis showed that the following variables were independently associated with positive serology for viral hepatitis: history of previous blood transfusions (adjusted $\mathrm{OR}=4.908,95 \% \mathrm{CI}=1.628-14.799, \mathrm{p}<0.01$ ), directed donation (adjusted $\mathrm{OR}=2.147,95 \% \mathrm{CI}=1.236-3.729, \mathrm{p}<0.01$ ), and choosing to self-exclude (adjusted $\mathrm{OR}=7.139,95 \% \mathrm{CI}=2.045$ 24.923, $\mathrm{p}<0.01)$.

\section{Comparative analysis of individuals with confidential self-exclusion}

We did not observe any significant differences between the donors who did or did not choose CSE of the donated blood with regard to age $(p=0.63)$, gender $(p=0.51)$, ethnicity $(p=0.56)$, marital status $(\mathrm{p}=1.00)$, education $(\mathrm{p}=1.00)$, sexual orientation $(p=1.00)$, body mass index $(p=0.13)$, being a health professional $(p=1.00)$, history of previous surgery $(p=0.28)$, history of previous blood transfusions $(\mathrm{p}=1.00)$, sexual promiscuity $(p=1.00)$, illicit drug use $(p=1.00)$, tattoos $(p=1.00)$, directed donation ( $p=0.16$ ), first donation ( $p=0.79)$, or donation to obtain blood test results $(\mathrm{p}=1.00)$ (Table 2).

\section{DISCUSSION}

Research on blood donors has shown a predominance of male donors, with a prevalence of $63.9-71.3 \% 0^{32-35}$. With respect to ethnicity, $96.2 \%$ of blood donors in the present study were Caucasian, which is consistent with the 2010 census in which $83.9 \%$ of the population of the State of Santa Catarina declared themselves as Caucasian ${ }^{36}$. In a similar study, the percentage of Caucasian blood donors in Southern Brazil was 99.2\% $\%^{33}$. The

TABLE 1 - Distribution of the clinical and epidemiological variables of 3,180 blood donors at the University Hospital of the Federal University of Santa Catarina between 2009 and 2010, according to their viral hepatitis serology results.

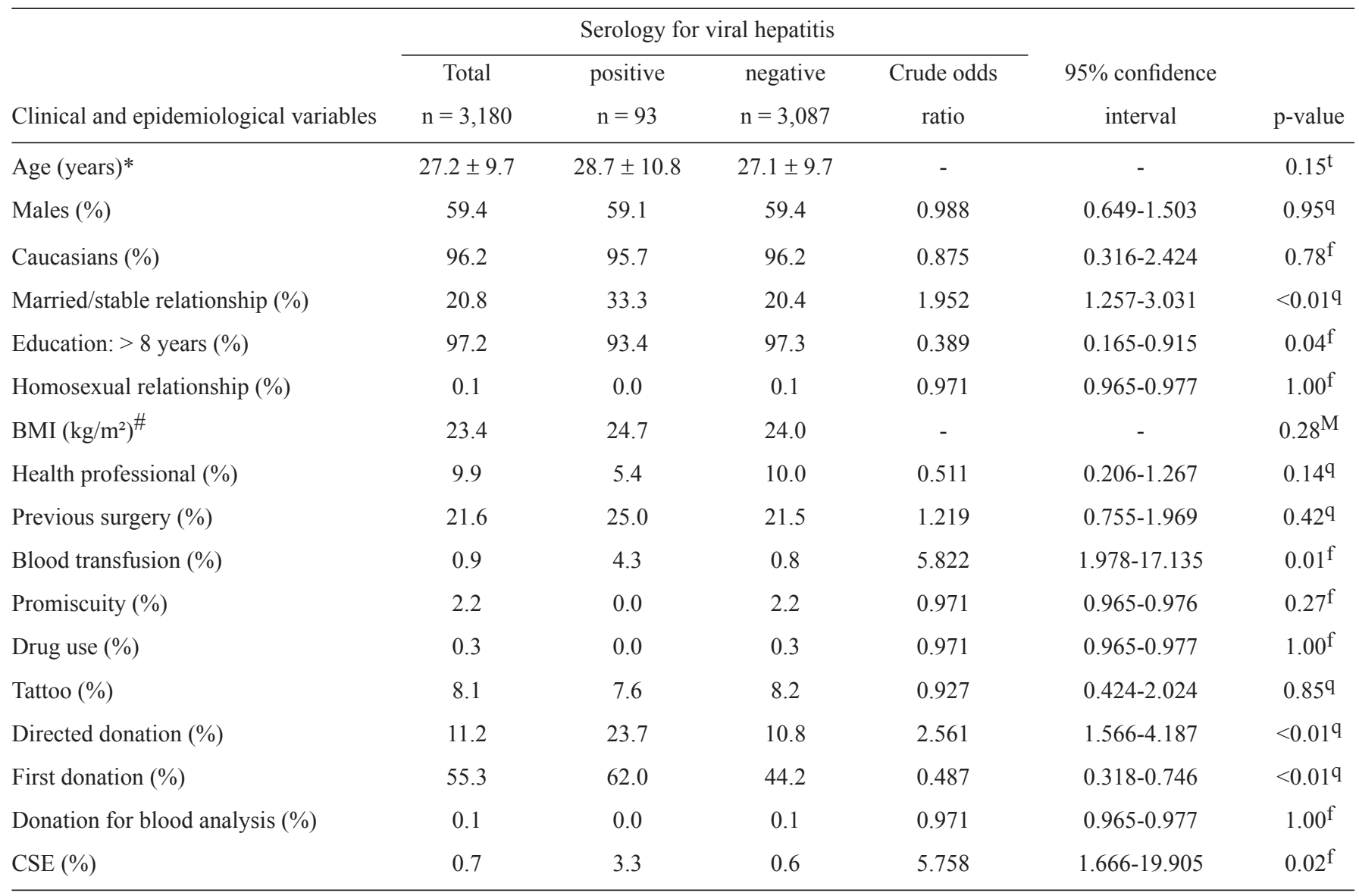

BMI: body mass index; CSE: confidential self-exclusion; *Mean \pm standard deviation; ${ }^{*}$ Median; ${ }^{\mathrm{t}}$ Student's t-test; ${ }^{\mathrm{m}}$ Mann-Whitney test;

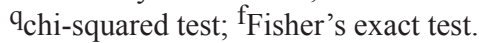


TABLE 2 - Comparative analysis of the clinical and epidemiological characteristics of 3,180 blood donors at the University Hospital of the Federal University of Santa Catarina according to their confidential self-exclusion status.

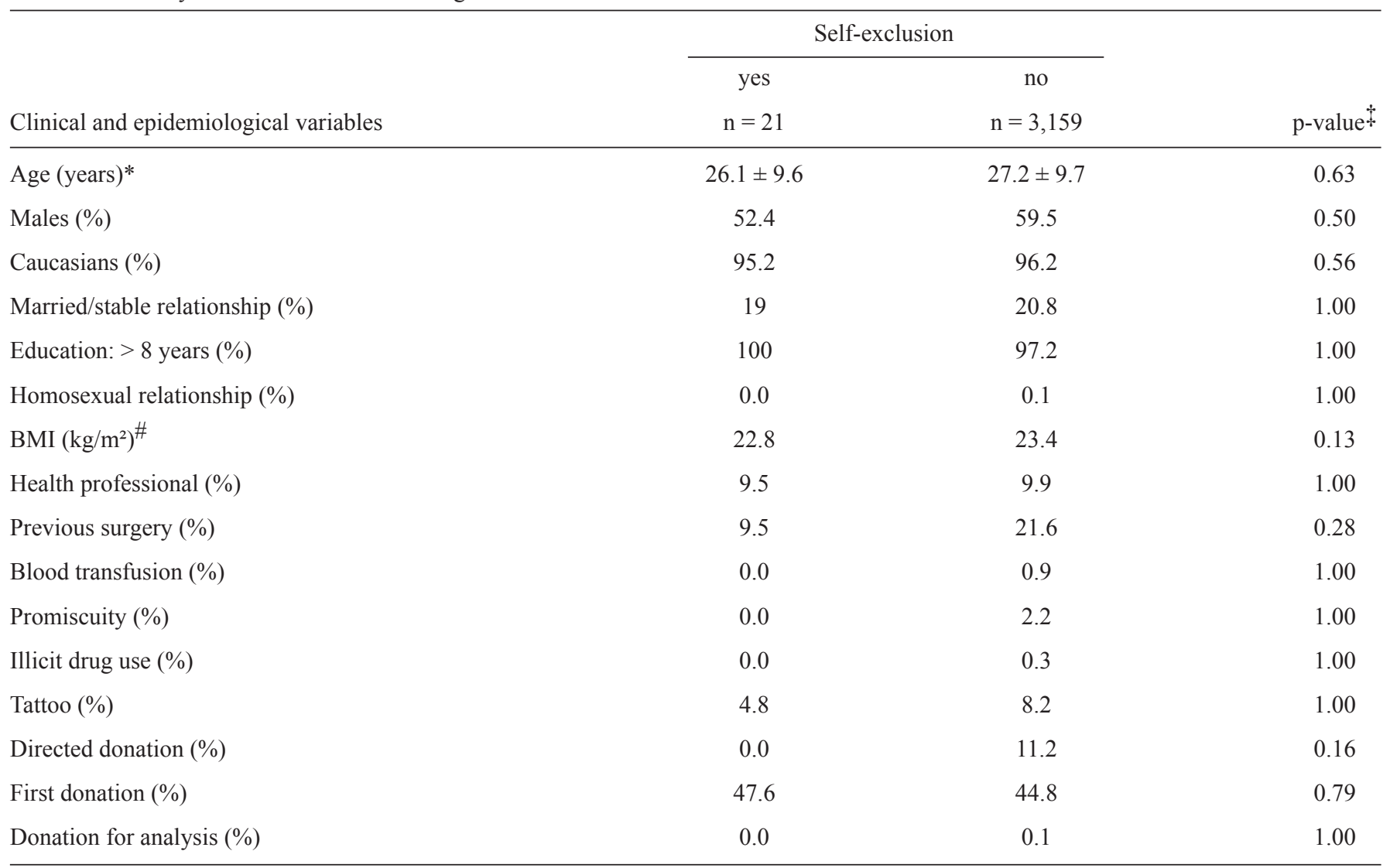

BMI: body mass index; *Mean \pm standard deviation; ${ }^{\#}$ Median; $\$$ Student's $t$-, Mann-Whitney, $\chi^{2}$, or Fisher's exact test, when appropriate for group comparisons.

prevalence of single $(79.2 \%)$ donors and donors who completed high $(97.2 \%)$ school was greater than that found in previous studies (34.4-49.0\% and 54.7-63.7\%, respectively) ${ }^{33,34}$, possibly reflecting the university population in this state.

The mean age in the present study was $27.2 \pm 9.7$ years. When the donors were distributed by age group, we found that the largest number of donations were from individuals between 20 and 24 years of age (35.2\% of donors). This result is inconsistent with the results of the Epidemiological Profile of Brazilian Blood Donor study performed in 2004, which indicated a higher frequency of donations from donors between 30 and 39 years of age $(28.3 \%$ in Brazil and $27 \%$ in Southern Brazil) ${ }^{34}$. In similar studies, the mean age of the donors was found to be between $36.5 \pm 11.0$ and $45.0 \pm 10.9$ years $^{32,33}$. This difference can be explained by the location of the blood bank at a university hospital and by the several blood donation campaigns promoted in every course, especially during the first year of university study. Sharma et al. ${ }^{37}$ reported that when the donor group is composed of mostly student volunteers, a lower proportion of donors with positive serology is observed ${ }^{37}$. Other studies addressing the epidemiological characteristics of blood donors showed that the presence of serological markers increases with the age of the donor ${ }^{33,38}$.
The prevalence of viral hepatitis markers in this study (HBsAg: $0.1 \%$, anti-HBc: $2.1 \%$, anti-HCV: $0.9 \%$ ) was lower compared with that in countries of high endemicity and similar to levels observed in areas with a low prevalence of these infections. In a study in Pakistan, $4.7 \%$ of the donors were found to be HBsAg-positive ${ }^{39}$. In Vietnam, the prevalences were 11.4 and $51.7 \%$ for HBsAg and anti-HBc, respectively ${ }^{40}$. These countries are located in South and Southeast Asia, regions with a high prevalence of hepatitis $\mathrm{B}^{41}$. In the United States, the prevalence of HBsAg in blood donors is $0.2 \%{ }^{42}$. In Europe, the distribution of individuals with HBsAg positivity is heterogeneous and varies according to region; Northern Europe has the lowest prevalence (less than $0.1 \%$ ), Western Europe has a prevalence of $0.1-0.5 \%$, and Southern and Eastern Europe have higher rates of $2.4 \%{ }^{43}$.

Worldwide, Egypt has the highest number of individuals with hepatitis $\mathrm{C}$ infection, with $16.8 \%$ of their donors being anti-HCV reactive ${ }^{44}$. However, the prevalence of hepatitis C infection in the general population of developed countries varies from $1-2 \%{ }^{45}$. In the United States, for example, approximately $0.5 \%$ of volunteer blood donors are anti-HCV reactive ${ }^{45}$.

The prevalence of positive serology for viral hepatitis found in this study is similar to those reported previously for Brazil by other authors (HBsAg: 0.14-0.78\%, anti-HBc: $2.05-13.44 \%$, 
anti-HCV: $0.34-1.14 \%)^{46-48}$. The prevalence of hepatitis B markers in Brazil varies greatly by region. The literature shows that Southern Brazil is an area of low endemicity, but the Western State of Santa Catarina has high endemicity. Data from 2001 showed an HBsAg prevalence of $0.6 \%$ in the blood donors in Santa Catarina, $1.5 \%$ in the Western region, $0.3 \%$ in the Southern region, and $0.6 \%$ in the capital, Florianópolis ${ }^{48}$. The anti-HBc rates also vary by location, with rates of $5.4 \%$ state-wide, $12.7 \%$ in the Western region, $2.9 \%$ in the Southern region, and $3.5 \%$ in Florianópolis ${ }^{48}$. Although the presence of anti- $\mathrm{HBc}$ antibodies in individuals who are $\mathrm{HBsAg-negative}$ may represent a previous infection (anti-HBs reactive), there are reports of the transmission of hepatitis B by blood transfusion from individuals in this group. For this reason, in places of intermediate prevalence, such as Brazil, anti-HBc-reactive individuals are treated as carriers, and the donated blood bags are discarded. A prevalence of $3 \%$ positivity for anti-HCV is estimated in the world population ${ }^{1}$. However, in Brazil, there is a prevalence of $0.8 \%$ of anti-HCV reactivity in blood donors ${ }^{1}$. Data indicate a prevalence of $0.3 \%$ of infection in the entire State of Santa Catarina $(0.2 \%$ in the west, $0.4 \%$ in the south, and $0.5 \%$ in the capital $)^{48}$.

Although blood transfusion is a recognized risk factor for the transmission of hepatitis B and C, PTH is currently virtually eradicated and is limited to a residual risk estimated only by mathematical models ${ }^{7}$. However, there is evidence suggesting that the global epidemic of HCV infection during the second half of the $20^{\text {th }}$ century was initiated and maintained by the increasing use of parenteral therapies and blood transfusions ${ }^{49}$. The main factors contributing to the reduction of post-transfusion hepatitis were the exclusion of commercial donations and the introduction in blood blanks of a serological screening program that was made progressively more sensitive ${ }^{11}$. After the implementation of mandatory HBsAg tests for blood donors in the United States in 1972, there was a $25 \%$ reduction in the rate of PTH in that country ${ }^{11}$. In Brazil, serological tests for HBV did not become mandatory until $1978^{50}$. Eighteen percent of multi-transfused patients were infected with $\mathrm{HCV}$ in the period before the introduction of mandatory screening for anti-HCV in 1993; afterward, the infection rate was reduced to $1.4 \% \%^{5,51}$.

Paid donations have been banned in Brazil for the past 33 years, although there are still some rewards provided to donors, such as free meals after donation ${ }^{33,52}$. The experiences of countries that stopped making remunerations to donors have shown that altruistic donations are insufficient to maintain a positive balance in the blood banks ${ }^{52}$. Linked donations, including donations among friends and relatives of patients who need transfusions ${ }^{52}$, are needed. These types of donations are performed by a wide spectrum of donors, ranging from family and friends to individuals who present themselves as such but who are actually receiving payment from the patient's family $^{53}$. Several studies have demonstrated a relationship between directed donation and higher rates of positive serology for infections transmitted by blood transfusions ${ }^{37,54-56}$. Dorsey et al. observed that this result could be explained by a greater number of first-time donators ${ }^{54}$.
In this study, a self-exclusion prevalence of $0.7 \%$ was found, which means that 22 bags of blood were discarded between 2009 and 2010 due to self-exclusion. This result is consistent with the findings of another study conducted in Southern Brazil, where $0.5 \%$ of the donations were discarded due to self-exclusion ${ }^{33}$. However, studies performed in Uberaba, State of Minas Gerais and Londrina, State of Paraná, showed higher self-exclusion rates $\left(2.7\right.$ and $3.2 \%$, respectively) ${ }^{57,58}$. Although no clinical or epidemiological variables were related to CSE in this study, previous studies have shown that males and first-time donors respond yes on the CSE form more frequently ${ }^{28,57-60}$. However, the greater the number of repeated donations, the fewer times the CSE form was used to self-exclude the donor's blood ${ }^{57,60}$.

Although a relationship between CSE and positive serology for viral hepatitis has been previously demontrated ${ }^{22,57,61}$, the ability of this practice to identify individuals in the testing window period was not previously addressed. The sensitivity and positive predictive values of CSE are quite low ${ }^{22,58,61-63}$, leading to the disposal of many blood bags from potentially healthy donors. The main factors related to problems with the CSE form are the difficulty of understanding the question ${ }^{26,28,57,58 \text {, }}$ the low socioeconomic status of the donors ${ }^{58,59}$, and the ineffective explanations by health professionals ${ }^{58}$. Another aspect to be considered is the varied format and content of the form, which are different for each blood bank ${ }^{57,58}$. It was shown that blood banks that use forms with plain text and color pictures have a lower frequency of affirmative responses to the self-exclusion choice, leading to a reduction in the disposal of low-risk blood bags and to an increase in the sensitivity of the procedure. Kean et al. ${ }^{64}$ observed a reduction of self-exclusion from $0.7 \%$ to $0.3 \%$ when the donor was properly and timely orientated to the CSE form ${ }^{64}$. Sumnig et al. demonstrated that the self-exclusion rate decreased from $0.7 \%$ to $0.5 \%$ after a change in the format of the question ${ }^{26}$.

Even with a high sensitivity and a significant positive predictive value, Martins et al. ${ }^{57}$ found three cases of positive serology after self-exclusion in less than 6 months (two cases of hepatitis $\mathrm{C}$ and one of HIV $)^{57}$. Other longitudinal studies should be conducted to address the real value of CSE. Educational measures, changes in the format and content of self-exclusion forms, and campaigns aimed to increase donors' motivation to re-donate rather than only captivate new donors are possible actions that may decrease the rate of self-exclusion and avoid the loss of safe donations.

Considering the literature and the findings of this study, it was observed that a history of a prior transfusion is directly related to positive serology for hepatitis in a blood bank, even when the date of the transfusion is not considered. Directed blood donations, although necessary, should be considered as high-risk donations for the transmission of viral hepatitis, as should donations from individuals who choose to self-exclude their donated blood, although a reduced number of individuals voted for self-exclusion in the present study. Finally, we conclude that a history of blood transfusion, repeated donations, and self-exclusion are factors that should be considered during viral hepatitis screening in blood banks. 


\section{ACKNOWLEDGMENTS}

This paper is presented as partial fulfillment of the requirements for the Medical Doctor (MD) degree from the Federal University of Santa Catarina.

\section{CONFLICT OF INTEREST}

The authors declare that there is no conflict of interest.

\section{REFERENCES}

1. Violantea MD, Nunes-Nateras R. Epidemiology of Hepatitis Virus B and C. Arch Med Res 2007; 38:606-611.

2. Te HS, Jensen DM. Epidemiology of Hepatitis B and C Viruses: A Global Overview. Clin Liver Dis 2010; 14:1-21.

3. Alleyne GA. Ensuring safe blood in the Americas. Rev Panam Salud Publica 2003; 13:65-67.

4. Ropero AM, Danovaro-Holliday MC, Andrus JK. Progress in vaccination against hepatitis B in the Americas. J Clin Virol 2005; 34 (suppl II):14-19.

5. Sociedade Brasileira de Hepatologia. Relatório do Grupo de Estudo da Sociedade Brasileira de Hepatologia. Epidemiologia da Infecção pelo Vírus da Hepatite C no Brasil. Gastroenterol Endosc Dig 1999; 18:53-58.

6. Dodd RY, Notari EP, Stramer SL. Current prevalence and incidence of infectious disease markers and estimated window-period risk in the American Red Cross blood donor population. Transfusion 2002; 42:975-979.

7. Maresch C, Schluter PJ, Wilson AD, Sleigh A. Residual infectious disease risk in screened blood transfusion from a high-prevalence population: Santa Catarina, Brazil. Transfusion 2008; 48:273-281

8. Polizzotto MN, Wood EM, Ingham H, Keller AJ, Australian Red Cross Blood Service Donor and Product Safety Team. Reducing the risk of transfusion-transmissible viral infection through blood donor selection: the Australian experience 2000 through 2006. Transfusion 2008; 48:55-63.

9. Beeson PB. Jaundice occurring one to four months after transfusion of blood or plasma. Report of seven cases. JAMA 1943; 121:1332-1334.

10. Grady GF, Chalmers TC. Risk of post-transfusion viral hepatitis. N Engl J Med 1964; 271:337-342.

11. Walsh JH, Purcell RH, Morrow AG, Chanock RM, Schmidt PJ. Posttransfusion hepatitis after open-heart operations. Incidenceafter the administration of blood from commercial and volunteer donor populations. JAMA 1970; 211:261-265.

12. Tobler LH, Busch MP. History of posttransfusion hepatitis. Clinical Chemistry 1997; 43:1487-1493.

13. Blumberg BS, Alter HJ, Visnich S. A "new" antigen in leukemia sera. JAMA 1965; 191:541-546.

14. Gocke DJ, Greenberg HB, Kavey NB. Hepatitis antigen. Detection of infectious blood donors. Lancet 1969; 2:248-249.

15. Gocke DJ, Greenberg HB, Kavey NB. Correlation of Australia antigen with posttransfusion hepatitis. JAMA 1970; 77:877-879.

16. Feinstone SM, Kapikian AZ, Purcell RH. Hepatitis A. Detection by immune electron microscopy of a virus-like antigen associated with acute illness. Science 1973; 182:1026-1028.

17. Stevens CE, Silbert JA, Miller DR, Dienstag JL, Purcell RH, Szmuness W. Serologic evidence of hepatitis A and B virus infections in thalassemia patients: a retrospective study. Transfusion 1978; 18:356-360.

18. Dienstag JL, Purcell HR, Alter HJ, Feinstone SM, Wong DC, Holland PV. Non-A, non-B post-transfusion hepatitis. Lancet 1977; 1:560-562.
19. Ezzell C. Candidate cause identified of non-A, non-B hepatitis [News] Nature 1988; 333:195.

20. Choo QL, Kuo G, Weiner AJ, Overby LR, Bradley DW, Houghton M. Isolation of a cDNA clone derived from a blood-borne non-A, non-B viral hepatitis genome. Science 1989; 244:359-361.

21. Alter HJ. To C or not to C: these are the questions. Blood 1995; 85:16811695.

22. Kasraian L, Tavasoli A. Positivity of HIV, hepatitis B and hepatitis C in patients enrolled in a confidential self-exclusion system of blood donation: a cross-sectional analytical study. Sao Paulo Med J 2010; 128:320-323

23. Eder AF, Menitove JE. Blood donations' past, present, and future: TRANSFUSION'S golden anniversary. Transfusion 2010; 50:1870-1877.

24. Lee WM. Hepatitis B virus infection. N Engl J Med 1997; 337:17331745.

25. Su PJ, Chen TC, Cheng HR, Li L, Lin KS, Kao JH, et al. The clinical significance of occult hepatitis B transfusion in Taiwan - a look-back study. Transfus Med 2010; 1:33-41.

26. Sümnig A, Konerding U, Kohlmann T, Greinacher A. Factors influencing confidential unit exclusions in blood donors. Vox Sanguinis 2010; 98 : e231-e240.

27. Soldan K, Ramsay ME, Robinson A, Hall AJ. Estimation of the risk of hepatitis B virus, hepatitis $\mathrm{C}$ virus and human immunodeficiency virus infectious donations entering the blood supply in England, 1993-2001. Vox Sanguinis 2003; 84:274-286.

28. Castro V. The role of confidential unit exclusion on blood safety. Rev Bras Hematol Hemoter 2009; 31:213-214.

29. Sloand EM, Pitt E, Klein HG. Safety of the blood supply. JAMA 1995; 274:1368-1373.

30. Ministério da Saúde. Resolution - RDC No 153 - [Technical Roules to Hemotherapy Procedures]. Brasília: Diário Oficial da União; 2004.

31. Ministério da Saúde - Resolution - RDC No 343 - [Technical Roules to Hemotherapy Procedures]. Brasília: Diário Oficial da União; 2003.

32. Baha W, Foullous A, Dersi N, They-They TP, Alaoui K, Nourichafi N, et al. Prevalence and risk factors of hepatitis $\mathrm{B}$ and $\mathrm{C}$ virus infections among the general population and blood donors in Morocco. BMC Public Health $2013 ; 13: 50$.

33. Silveira L, Schiavon LL, Silva KP, Lopes TB, Zaccaron MR, NarcisoSchiavon JL. Clinical and epidemiological profile of blood donors with positive serology for viral hepatitis in southern Brazil. Rev Soc Bras Med Trop 2011; 44:269-273.

34. Agência Nacional de Saúde (Anvisa). Brazilian Blood Donor Profile. [Internet]; Brasília: Anvisa 2004 [Cited 2012 August 02]. Available at: http://www.anvisa.gov.br/hotsite/doador_sangue/pdsbfiles/pdf/Tabdoadores/ Brasil_d.pdf/.

35. Almeida-Neto C, Murphy EL. Prevalence of serologic markers for hepatitis $\mathrm{B}$ and $\mathrm{C}$ viruses in Brazilian blood donors and incidence and residual risk of transfusion transmission of hepatitis $\mathrm{C}$ virus. Transfusion 2013; 53:827-834.

36. Instituto Brasileiro de Geografia e Estatística (IBGE). Brazilian Demographic Census [Internet]; Brasília: IBGE; 2010. [Cited 2012 August 08]. Available at: http://www.ibge.gov.br/home/estatistica/ populacao/censo2010/default.shtm/.

37. Sharma RR, Cheema R, Vajpayee M, Rao U, Kumar S, Marwaha N, et al. Prevalence of markers of transfusion transmissible diseases in voluntary and replacement donors. Natl Medic J India 2004; 17:19-21.

38. Chávez JH, Campana SG, Hass P. An overview of hepatitis B in Brazil and in the state of Santa Catarina. Rev Panam Salud Publica 2003; 14:91-96.

39. Mujeeb AS, Nanan D, Sabir S, Altaf A, Kadir M. Hepatits B and C infection in first-time blood-donors in Karachi - a possible subgroup for sentinel surveillance. East Mediterr Health J 2006; 12:735-741.

40. Viet L, Lan NT, Ty PX, Bjorkvoll B, Hoel H, Gutteberg T, et al. Prevalence of hepatits B \& hepatitis C virus infections in potential blood donors in rural Vietnam. Indian J Med Res 2012; 136:74-81. 
41. Candotti D, Allain JP. Transfusion-transmitted hepatitis B virus infection. J Hepatol 2009; 51:789-809.

42. Glynn SA, Kleinman SH, Schreiber GB, Busch MP, Wright DJ, Smith JW, et al. Trends in incidence and prevalence of major transfusiontransmissible viral infections in US blood donors, 1991 to 1996. Retrovirus Epidemiology Donor Study (REDS). JAMA 2000; 284:229-235.

43. Goudeau A. Epidemiology and eradication strategy for hepatitis B in Europe. The European Regional Study Group. Vaccine 1990; 8:S113-S116.

44. Awadalla HI, Ragab MH, Nassar NA, Osman MAH. Risk factors of hepatits $\mathrm{C}$ infection among egyptian blood donors. Cent Eur J Public Health 2011; 19:217-221.

45. Di Bisceglie AM. Hepatitis C. Lancet 1998; 351:351-355.

46. Andrade AF, Oliveira-Silva M, Silva SGC, Motta IJF. Seroprevalence of hepatitis B and C virus markers among blood donors in Rio de Janeiro, Brazil, 1998-2005. Mem Inst Oswaldo Cruz 2006; 101:673-676.

47. Vasconcellos HCFF, Yoshida CFT, Vanderborght BOM, Schatzmayr HG. Hepatitis B and C prevalence among blood donors in south region of Brazil. Mem Inst Oswaldo Cruz 1994; 89:503-507.

48. Rosini N, Mousse D, Spada C, Treitinger A. Seroprevalence of HBsAg, Anti-HBc and Anti-HCV in Southern Brazil, 1999-2001. Braz J Infec Dis 2003; 7:262-267.

49. Prati D. Transmission of hepatitis C virus by blood transfusions and other medical procedures: A global review. J Hepatol 2006; 45:607-616.

50. Ministério da Saúde. State of São Paulo. Decree No. 12479 of 18 October 1978 [Internet]. Published in the Government Secretariat, on 18/10/1978; 1978. [Cited 2012 August 12]. Available at http://www.anvisa.gov.br/ legis/decretos/12479_78.htm/.

51. Ministério da Saúde. Ordinance No. 1376, of November 19, 1993 [Internet]. Published in the Diário Oficial da União on 02/12/1993; 1993. [Cited 2012 August 12]. Available at http://www.planalto.gov.br/ ccivil_03/decreto-lei/del1376.htm/.

52. Guerra CCC. Fim da doação remunerada de sangue no Brasil faz 25 anos. Rev Bras Hematol Hemoter 2005; 27:1-3.

53. World Health Organization (WHO) [Internet]. WHO Global Database on Blood Safety, 2004-2005. Geneva: WHO; 2008. [Cited 2012 August 12]. Available at: http://www.who.int/bloodsafety/global_database/en/.

54. Dorsey KA, Moritz ED, Steele WR, Eder AF, Stramer SL. A comparison of human immunodeficiency virus, hepatitis virus, hepatitis B virus, and human T-lymphotropic virus marker rates for directed versus volunteer blood donations to the American Red Cross during 2005 to 2010. Transfusion 2013; 53:1250-1256.

55. Pereira A, Sanz C, Tassies D, Ramirez B. Do patient-related blood donors represent a threat to the safety of the blood supply? Haematologica 2002; $87: 427-433$.

56. Sultan F, Mehmood T, Mahmood MT. Infectious pathogens in volunteer and replacement blood donors in Pakistan: a ten-year experience. Int J Infect Dis 2007; 11:407-412.

57. Martins RJ, Martins RA, Moraes-Souza H, Barbosa VF, Pereira GA, Eustáquio JMJ. Self-exclusion profiles of blood donors of the Regional Blood Bank in Uberaba, Brazil (HRU) in the period of 1996 to 2006. Rev Bras Hematol Hemoter 2009; 31:222-227.

58. Vogler IH, Saito M, Spinoza AA, Silva MC, Munhoz E, Reiche EMV. Effectiveness of confidential unit exclusion in screening blood donors of the regional blood bank in Londrina, Paraná State. Rev Bras Hematol Hemoter 2011; 33:347-352.

59. Farhadi E, Gharehbaghian A, Karimi G, Samiee S, Tavasolli F, Salimi Y. Efficacy of the Confidential Unit Exclusion Option in Blood Donors in Tehran, Iran, Determined by Using the Nucleic Acid Testing Method in 2008-2009. Hepat Mon 2011; 11:907-912.

60. Thaikruea L, Nantachit N, Leetrakool N, Fongsatitkul L, Sompan P, Heaton A, et al. Assessment of a self-deferral form for screening blooddonors, Chiang Mai University Hospital, Thailand. Southeast Asian J Trop Med Public Health 2008; 39:906-912.

61. Korelitz JJ, Williams AE, Busch MP, Zuck TF, Ownby HE, Matijas LJ, et al. Demographic characteristics and prevalence of serologic markers among donors who use the confidential unit exclusion process: the Retrovirus Epidemiology Donor Study. Transfusion 1994; 34:870-876.

62. Zou S, Notari EPt, Musavi F, Dodd RY. Current impact of the confidential unit exclusion option. Transfusion 2004; 44:651-657.

63. Food and Drug Administration [Internet]. Department of Health \& Human Services. Revised recommendations for the prevention of human immunodeficiency virus (HIV) transmission by blood and blood products; 1992. [Cited 2012 September 01]. Available at: http://www.fda.gov/downloads/ BiologicsBloodVaccines/GuidanceComplianceRegulatoryInformation/ OtherRecommendationsforManufacturers/MemorandumtoBloodEstablishments/ UCM062834.pdf/.

64. Kean CA, Hsueh Y, Querin JJ, Keating LJ, Allensworth DD. A study of confidential unit exclusion. Transfusion 1990; 30:707-709. 